\title{
A membrane-bound pyrophosphatase from respiratory membranes of Rhodospirillum rubrum
}

\author{
Irma Romero, ${ }^{1}$ Alberto Gómez-Priego ${ }^{2}$ and Heliodoro Celis ${ }^{1 *}$ \\ ${ }^{1}$ Departamento de Bioenergética, Instituto de Fisiología Celular, Apartado Postal 70-600, and ${ }^{2}$ Departamento de Ecología \\ Humana, Facultad de Medicina, UNAM, México 04510, DF
}

(Received 20 May 1991; revised 5 August 1991; accepted 20 August 1991)

\begin{abstract}
A pyrophosphatase activity was found in respiratory membranes of Rhodospirillum rubrum. This activity was specific for pyrophosphate and was inhibited by dicyclohexylcarbodiimide, $\mathrm{NaF}$ and pyrophosphate analogues, but not by oligomycin or $\mathrm{LiCl}$. The divalent cation selectivity was $\mathrm{Zn}^{2+}>\mathrm{Mg}^{2+}>\mathrm{Co}^{2+}>\mathrm{Ca}^{2+}$, and the $\mathrm{pH}$ dependence was the same as that of the membrane-bound pyrophosphatase of chromatophores (optimum pH 6.5). The pyrophosphate hydrolysis activity of respiratory membranes was inhibited by 1-butanol. The enzyme was solubilized by Triton X-100, and the activity of the solubilized enzyme was stimulated by phospholipids. The respiratory-membrane enzyme ran in native electrophoresis with the same $R_{F}$ as the membrane-bound pyrophosphatase of chromatophores. Antibodies raised against both enzymes cross-reacted with each other. These findings show that a membrane-bound pyrophosphatase is present in respiratory membranes of $R$. rubrum and is similar to the enzyme of photosynthetic membranes.
\end{abstract}

\section{Introduction}

The photosynthetic bacterium Rhodospirillum rubrum is a member of the family Rhodospirillaceae. These organisms are remarkably versatile in obtaining growth energy through alternative mechanisms. They can grow in the dark chemotrophically in the presence of $\mathrm{O}_{2}$ by the oxidation of substrates, or phototrophically in the absence of $\mathrm{O}_{2}$.

In phototrophically grown bacteria, extensions and modifications of the cytoplasmic membrane are formed and can be easily isolated. These pigmented membranes, called chromatophores, contain the photosynthetic electron transport and ATP synthesis enzymes. H. Baltscheffsky et al. (1966) reported that chromatophores contain a membrane-bound pyrophosphatase which is coupled reversibly to the $\mathrm{H}^{+}$gradient (Guillory \& Fisher, 1972; Moyle et al., 1972). In chemotrophically dark-grown cells, the fragments derived from the cytoplasmic membrane are enriched in respiratory chain activity (Taniguchi \& Kamen, 1965; Thorne et al., 1969). These membranes contain very low concentrations of bacteriochlorophyll and carotenoids. However there have been no reports of a bound pyrophosphatase in respiratory membranes.

In this work, we report the existence and characteristics of a membrane-bound pyrophosphatase activity in respiratory membranes of $R$. rubrum, and compare this enzyme with the membrane-bound pyrophosphatase of chromatophores.

\section{Methods}

Cell cultures and membrane preparations. Rhodospirillum rubrum (ATCC 11170) was grown chemotrophically in the dark at $30^{\circ} \mathrm{C}$. We used 1 litre Erlenmeyer flasks, which contained $200 \mathrm{ml}$ of the growth medium described by Cohen-Bazire et al. (1957); intense aeration was provided by gyratory shaking. Cells were harvested during the exponential phase and contained $0 \cdot 3 \mu \mathrm{g}$ bacteriochlorophyll $(\mathrm{mg}$ cell protein $)^{-1}$. The respiratory membranes were prepared as described by Fenoll \& Ramírez (1984). For phototrophic growth, the cells were grown anaerobically in light from tungsten lamps $(30 \mathrm{~W}) 30 \mathrm{~cm}$ from the flasks and at $30^{\circ} \mathrm{C}$ in the same medium as above. The bacteria were harvested in the exponential growth phase and contained $25 \mu \mathrm{g}$ bacteriochlorophyll (mg protein) ${ }^{-1}$. The chromatophores were prepared by ultrasonic rupture of the cells and centrifugation as previously described (Celis et al., 1985). For experiments with divalent cations, the residual $\mathrm{Mg}^{2+}$ was eliminated from the respiratory membranes and chromatophores by washing them with $5 \mathrm{mM}$-EDTA, pH 7.5, $5 \mathrm{~mm}$ EGTA, pH 7.5, and $10 \mathrm{~mm}-\mathrm{Tris} / \mathrm{HCl}, \mathrm{pH} 7.5$, followed by a second washing with $10 \mathrm{~mm}$-Tris/ $\mathrm{HCl}, \mathrm{pH} 7 \cdot 5$. Cytoplasmic pyrophosphatase of $R$. rubrum was partially purified as described by Klemme \& Gest (1971).

Pyrophosphatase and ATPase activities. Hydrolysis of $\mathrm{PP}_{\mathrm{i}}$ and ATP was determined in the dark with a Green safety light. The solutions contained: for $\mathrm{PP}_{\mathrm{i}}$ hydrolysis, $50 \mathrm{mM}-\mathrm{Tris} / \mathrm{maleate}, \mathrm{pH} 6.5,2.0 \mathrm{mM}-$ sodium pyrophosphate and $5.0 \mathrm{~mm}-\mathrm{MgCl}_{2}$; for ATP hydrolysis, $50 \mathrm{~mm}$ - 
Tris/acetate, pH 7.5, 3.0 mM-ATP, 5.0 mM- $\mathrm{MgCl}_{2}, 1.45 \mathrm{~mm}$-phosphoenol pyruvate and $7 \mu \mathrm{g}$ pyruvate kinase. The final concentration of chromatophores or respiratory membranes was $1 \mathrm{mg}$ protein in $0.5 \mathrm{ml}$ mixture. The temperature was $30^{\circ} \mathrm{C}$. The reaction was stopped by adding trichloroacetic acid to a final concentration of $6.0 \%$. Phosphate was determined in the supernatant as described by Sumner (1944).

Protein and bacteriochlorophyll determinations. Protein was measured by the method of Lowry. Bacteriochlorophyll content was determined according to Clayton (1963).

Solubilization of membrane-bound pyrophosphatase. The solubilization of the pyrophosphatase of respiratory and photosynthetic membranes was done according to the procedure of Nyrén et al. (1984) as follows: $1 \mathrm{ml}$ of respiratory or photosynthetic membranes $\left(70 \mathrm{mg}\right.$ protein $\left.\mathrm{ml}^{-1}\right)$ was suspended in $7 \mathrm{ml}$ buffer containing $50 \mathrm{~mm}$-Tris/ $\mathrm{HCl}, \mathrm{pH} 8.2,25 \%$ (v/v) ethylene glycol, $600 \mathrm{mM}-\mathrm{MgCl}_{2}, 0.2 \mathrm{~mm}$-dithioerythritol and various concentrations of Triton X-100. After gentle stirring on ice for $20 \mathrm{~min}$, the suspension was centrifuged at $110000 \mathrm{~g}$ for $2 \mathrm{~h}$, and the supernatants were analysed for pyrophosphatase activity. The phospholipids were prepared as follows: $L-\alpha$-lecithin from soybean, commercial grade (Sigma) was washed with acetone and ether (Kagawa \& Racker, 1966) and $60 \mathrm{mg} \mathrm{ml}^{-1}$ of washed phospholipids were suspended in $10 \mathrm{mM}-\mathrm{Tris} / \mathrm{HCl}, \mathrm{pH} 7 \cdot 5$, and sonicated to give a uniform suspension which was used for experiments.

Gel electrophoresis. The solubilized respiratory and photosynthetic pyrophosphatases were analysed by non-denaturing electrophoresis using the method of Davis (1964) on slab gels (1.5 mm thickness). Electrophoresis, with $10 \%$ acrylamide running gels and $4.5 \%$ stacking gel, was carried out at $4{ }^{\circ} \mathrm{C}$ in $24.8 \mathrm{mM}$-Tris, $191.8 \mathrm{~mm}$-glycine buffer, pH 8.3 , for $5 \mathrm{~h}$ at $30 \mathrm{~mA}$ per gel. To localize the pyrophosphatase activity, the gels were incubated for $30 \mathrm{~min}$ at $37^{\circ} \mathrm{C}$ in $50 \mathrm{~mm}$ Tris/ $\mathrm{HCl}$, pH 8.5, $3 \mathrm{~mm}$-sodium pyrophosphate and $5 \mathrm{~mm}-\mathrm{MgCl}_{2}$. The gels were then washed once with water and immersed in a solution at $45{ }^{\circ} \mathrm{C}$ of $10 \%$ ascorbate and $0.42 \%$ ammonium molybdate in $0.5 \mathrm{M}$ $\mathrm{H}_{2} \mathrm{SO}_{4}(1: 6, \mathrm{v} / \mathrm{v})$ until blue bands showing the position of enzyme were clearly visible. Gels were rinsed quickly with distilled water, and immediately scanned at $660 \mathrm{~nm}$ with a Beckman DU-50 spectrophotometer gel scanner.

Antibodies. The bands with pyrophosphatase activity were excised and homogenized. Mouse antibodies were raised against these mixtures by the intramuscular injection of $0.1 \mathrm{ml}$ of the preparation $(7 \mu \mathrm{g}$ protein) in $0.1 \mathrm{ml}$ of Freund's complete adjuvant and a intraperitoneal injection of $0.9 \mathrm{ml}(60 \mu \mathrm{g}$ protein) of the mixture without adjuvant. This procedure was repeated on days 7 and 21 after the first inoculation. Bleeding was performed $7 \mathrm{~d}$ after the last injection and antisera were used for ELISA experiments.

Two-dimensional denaturing (sodium lauryl sulphate) polyacrylamide gel electrophoresis of the bands with pyrophosphatase activity showed a band around $56 \mathrm{kDa}$, and no contaminants were detected.

Enzyme-linked immunosorbent assay (ELISA). Indirect ELISA was done as described by Nakamura et al. (1986). ELISA immunoplates (Dynatech Immulon) were adsorbed with solubilized respiratory and photosynthetic pyrophosphatase, which reacted with the antisera. Anti-mouse antibodies conjugated with horse-radish peroxidase were then added and the colour reaction was developed with orthophenylenediamine and $\mathrm{H}_{2} \mathrm{O}_{2}$ as substrate and stopped with $2.5 \mathrm{M}$ $\mathrm{H}_{2} \mathrm{SO}_{4}$. Absorbance was read at $492 \mathrm{~nm}$ in a Bio-Rad EIA reader.

Reproducibility. The experiments shown in each Figure or Table were all repeated two or more times to confirm that the results were reproducible. Representative data are presented.
Table 1. Comparison of specific activities of pyrophosphatase (PPise) and ATPase in chromatophores and respiratory membranes of Rhodospirillum rubrum

\begin{tabular}{|c|c|c|c|c|}
\hline & \multicolumn{2}{|c|}{$\underset{(\text { mg protein) })^{-1}}{\mu \mathrm{mol} \mathbf{P}_{\mathbf{i}} \mathbf{h}^{-1}}$} & \multicolumn{2}{|c|}{$\begin{array}{l}\mu \mathrm{mol} \mathbf{P}_{\mathrm{i}} \mathbf{h}^{-1} \\
(\mathrm{mg} \mathrm{Bchl})^{-1}\end{array}$} \\
\hline & $\mathbf{P P}_{\mathrm{j}}$ ase & ATPase & $\mathbf{P P}_{\mathrm{i}}$ ase & ATPase \\
\hline Chromatophores & 6.8 & $2 \cdot 4$ & $119 \cdot 0$ & $42 \cdot 1$ \\
\hline Respiratory membranes & 3.7 & $4 \cdot 1$ & $50320 \cdot 0$ & 55983.0 \\
\hline
\end{tabular}

\section{Results and Discussion}

The pyrophosphatase and $\mathrm{H}^{+}$-ATPase activities of respiratory membranes and chromatophores are shown in Table 1. When the $\mathbf{P P}_{\mathrm{i}}$ hydrolysis activity was normalized with respect to protein, the specific activity found in respiratory membranes was $30-50 \%$ of that found in chromatophores; however, when the ATPase activity was compared, the ATPase activity was higher in respiratory membranes than in chromatophores. When the specific activities for hydrolysis of $P P_{i}$ and ATP were normalized with respect to bacteriochlorophyll, very high activities of both enzymes were found. This was due to the decrease in bacteriochlorophyll content in respiratory membranes. Since it is known that ATP hydrolysis is catalysed by the same enzyme in chromatophores and respiratory membranes (Melandri et al., 1971) these findings strongly imply that the $\mathrm{PP}_{\mathrm{i}}$ hydrolysis found in respiratory membranes was not due to chromatophore contamination.

\section{Effects of inhibitors and substrate specificity of the pyrophosphatase of respiratory membranes}

The pyrophosphatase and $\mathrm{H}^{+}$-ATPase activities in chromatophores and respiratory membranes were compared in their sensitivity to classical inhibitors of these activities. These data are shown in Table 2. M. Baltscheffsky et al. (1966) found that oligomycin strongly inhibits the $\mathrm{H}^{+}$-ATPase of chromatophores, but not the membrane-bound pyrophosphatase, which we confirmed. Dicyclohexylcarbodiimide (DCCD) is an inhibitor of the $\mathrm{H}^{+}$channel of both mitochondrial and chromatophore $\mathrm{H}^{+}$-ATPases (Schmid et al., 1981; Sebald \& Hoppe, 1981) and also inhibits the pyrophosphatase activity (Baltscheffsky et al., 1982). Table 2 shows that the $\mathrm{H}^{+}-\mathrm{ATPase}$ and pyrophosphatase of chromatophores and respiratory membranes were inhibited by $480 \mu \mathrm{M}-\mathrm{DCCD}$. NaF is a specific inhibitor of cytoplasmic and membrane-bound pyrophosphatases (Keister \& Minton, 1971a) but not $\mathrm{H}^{+}$-ATPase. The same was found in this work for the pyrophosphatase 
Table 2. Effect of various inhibitors on the ATPase and pyrophosphatase activities of chromatophores and respiratory membranes

Conditions of measurement as in Methods.

\begin{tabular}{|c|c|c|c|c|}
\hline \multirow[b]{3}{*}{ Compound } & \multirow[b]{3}{*}{ Concentration } & \multicolumn{3}{|c|}{ Inhibition (\%) } \\
\hline & & \multirow{2}{*}{$\frac{\text { ATPase }}{\text { Chromatophores* }}$} & \multicolumn{2}{|c|}{ Pyrophosphatase } \\
\hline & & & Chromatophores $\dagger$ & $\begin{array}{l}\text { Respiratory } \\
\text { membranes } \ddagger\end{array}$ \\
\hline $\begin{array}{l}\text { Oligomycin } \\
\text { DCCD } \\
\mathrm{NaF} \\
\text { Imidodiphosphate } \\
\text { Methylenediphosphate } \\
\text { LiCl§ }\end{array}$ & $\begin{array}{l}20 \mu \mathrm{g} \mathrm{ml}^{-1} \\
480 \mu \mathrm{M} \\
10 \mathrm{mM} \\
20 \mathrm{mM} \\
20 \mathrm{mM} \\
2 \mathrm{M}\end{array}$ & $\begin{array}{r}85 \cdot 3 \\
85 \cdot 0 \\
8 \cdot 6 \\
- \\
0.0 \\
96 \cdot 6\end{array}$ & $\begin{array}{c}1.5 \\
65 \cdot 1 \\
100 \cdot 0 \\
80 \cdot 0 \\
50 \cdot 0 \\
0 \cdot 0\end{array}$ & $\begin{array}{c}4 \cdot 7 \\
87 \cdot 4 \\
100 \cdot 0 \\
74 \cdot 0 \\
60.0 \\
0.09\end{array}$ \\
\hline \multicolumn{5}{|c|}{ 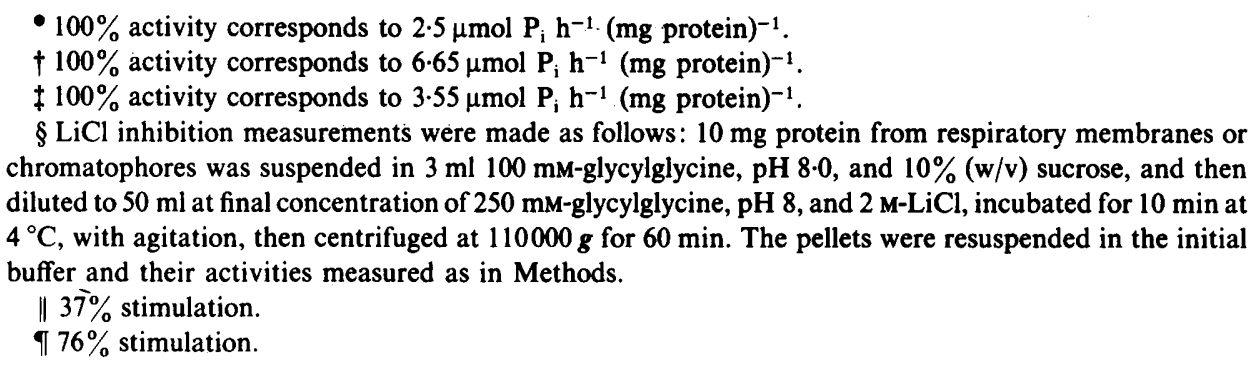 } \\
\hline
\end{tabular}

activity of respiratory membranes. Moreover, the competitive inhibitors methylenediphosphate and imidodiphosphate inhibit the membrane-bound pyrophosphatase of chromatophores (Keister \& Minton, 1971b; Nyrén \& Baltscheffsky, 1983) and we found that they also inhibited the pyrophosphatase of respiratory membranes. $\mathrm{LiCl}$, at high concentrations $(2 \mathrm{M})$ inhibits the $\mathrm{H}^{+}$-ATPase of chromatophores, because it releases the $\beta$-subunit from $F_{1}$ (Pilosoph et al., 1977). However, although the membrane-bound pyrophosphatase of chromatophores is said to be insensitive to this compound (Guillory \& Fisher, 1972), we found this enzyme was activated. The respiratory membranes pyrophosphatase activity was also activated by $\mathrm{LiCl}$ (Table 1). In summary, the pattern of sensitivity to inhibitors of the pyrophosphatase of respiratory membranes was the same as that found in chromatophores.

To assay the specificity of the pyrophosphatase present in respiratory membranes, $\alpha$-glycerophosphate, $\beta$-glycerophosphate, D-glucose 1-phosphate, D-glucose 6-phosphate, AMP and p-nitrophenylphosphate were tested at $2 \mathrm{mM}$ concentration (data not shown). Except for ADP, which is hydrolysed at $20 \%$ the rate of $P P_{i}$, none of these compounds were hydrolysed by the enzyme at a rate of more than $2 \%$ of the rate of $\mathrm{PP}_{\mathrm{i}}$. Thus, the pyrophosphatase of respiratory membranes is highly specific for $\mathrm{PP}_{\mathrm{i}}$ as substrate.

\section{Effect of $\mathrm{pH}$ and divalent cations}

To compare the pyrophosphatase of respiratory membranes with the one present in chromatophores, two kinetic characteristics were studied: the $\mathrm{pH}$ dependence and the divalent cation requirement. The $\mathrm{pH}$ profile obtained for the $\mathrm{PP}_{\mathrm{i}}$ hydrolysis in chromatophores and respiratory membranes is shown in Fig. 1. The $\mathrm{pH}$ optimum for chromatophores was 6.5 , as reported previously (Celis \& Romero, 1987). Although the pyrophosphatase activity in respiratory membranes was lower than in chromatophores, the $\mathrm{pH}$ optimum was the same. Moreover, the optimum $\mathrm{pH}$ for cytoplasmic pyrophosphatase of $R$. rubrum is 8.6-9.5 (Klemme \& Gest, 1971). This comparison indicates that the pyrophosphatase activity found in respiratory membranes was not due to cytoplasmic pyrophosphatase contamination.

The membrane-bound pyrophosphatase of chromatophores, like most microbial pyrophosphatases, requires $\mathrm{Mg}^{2+}$ for hydrolysis (Lathi, 1983). $\mathrm{Mg}^{2+}$ forms a $\mathrm{Mg}-\mathrm{PP}_{\mathrm{i}}$ complex which is the true substrate for the enzyme (Randahl, 1979; Celis et al., 1985). Recently, we reported that the $\mathrm{Zn}-\mathrm{PP}_{\mathrm{i}}$ complex at low concentrations is a better substrate than the $\mathbf{M g}-\mathrm{PP}_{\mathrm{i}}$ complex (Celis \& Romero, 1987). Fig. 2 shows the cation dependence of the pyrophosphatase of respiratory membranes. Both 


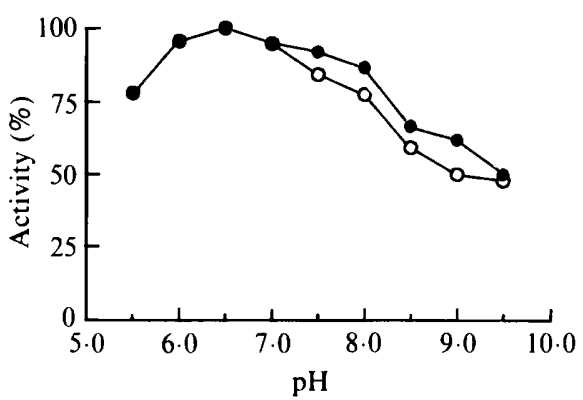

Fig. 1. $\mathrm{pH}$ profiles of pyrophosphatase of chromatophores and respiratory membranes. The incubation media contained $50 \mathrm{~mm}$ Tris/maleate at the $\mathrm{pH}$ values indicated in the abscissa, $2 \mathrm{~mm}$-sodium pyrophosphate, $5 \mathrm{mM}-\mathrm{MgCl}_{2}$ and $1 \mathrm{mg}$ of protein from chromatophores $(O)$ or respiratory membranes $(\bullet)$.

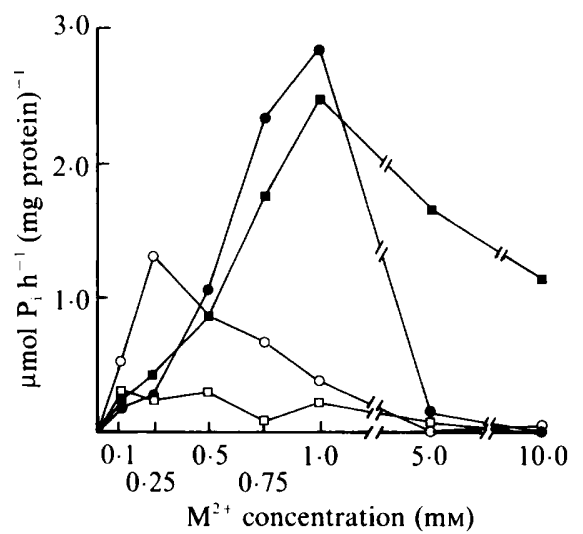

Fig. 2. Effect of divalent cations on the pyrophosphatase activity of respiratory membranes from Rhodospirillum rubrum. The assay medium contained: $50 \mathrm{~mm}$-Tris/maleate, pH 6.5, $0.67 \mathrm{~mm}$-sodium pyrophosphate and the indicated concentration of $\mathrm{Co}^{2+}(O), \mathrm{Ca}^{2+}(\square), \mathrm{Mg}^{2+}(\square)$ or $\mathrm{Zn}^{2+}(\bullet)$.

$\mathrm{Mg}-\mathrm{PP}_{\mathrm{i}}$ and $\mathrm{Zn}-\mathrm{PP}_{\mathrm{i}}$ were good substrates for the pyrophosphatase activity, and $\mathrm{Co}-\mathrm{PP}_{\mathrm{i}}$ was less efficient. Very low activity was found with $\mathrm{Ca}-\mathrm{PP}_{\mathrm{i}}$. At high concentrations $(>1.0 \mathrm{mM}), \mathrm{Zn}^{2+}$ inhibited the activity completely and $\mathrm{Mg}^{2+}$ inhibited it partially. This was probably due to the presence of free $\mathrm{Zn}^{2+}$ and free $\mathrm{Mg}^{2+}$ at these high concentrations (Celis \& Romero, 1987). The profile of divalent cation requirement obtained for respiratory-membrane pyrophosphatase was the same as that obtained by Celis \& Romero (1987) for the membrane-bound pyrophosphatase of chromatophores.

These observations strongly suggest two points. On the one hand, the pyrophosphatase found in respiratory membranes is very similar to that of chromatophores, and may be the same enzyme. On the other hand, the pyrophosphatase is a different molecular entity from the $\mathrm{H}^{+}$-ATPase.

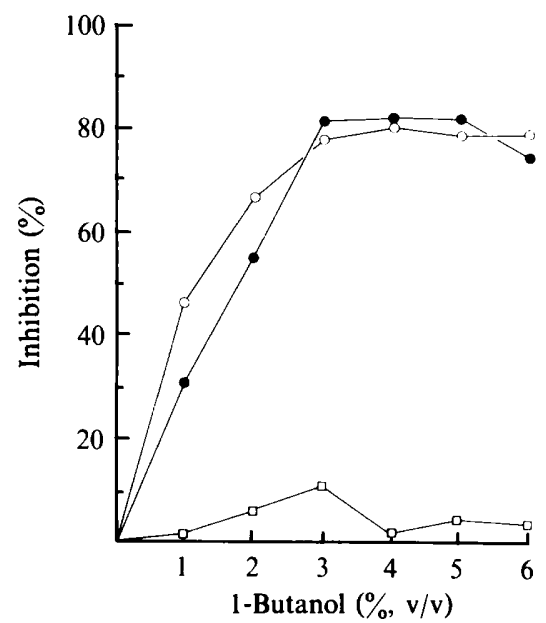

Fig. 3. Effect of 1-butanol on the activity of pyrophosphatase of chromatophores, respiratory membranes and cytoplasmic pyrophosphatase. The reaction mixture was as in Methods, and contained $50 \mu \mathrm{g}$ protein of cytoplasmic pyrophosphatase $\left(\mathrm{PP}_{\mathrm{i}}\right.$ ase $)$ where indicated. The maximal activity values $(100 \%)$ were: for chromatophores $(O)$, $6.5 \mu \mathrm{mol} \mathrm{P}_{\mathrm{i}} \mathrm{h}^{-1}$ (mg protein) $)^{-1}$; for respiratory membranes (๑), $3.4 \mu \mathrm{mol} \mathrm{P}_{\mathrm{i}} \mathrm{h}^{-1}$ (mg protein) $)^{-1}$; and for cytoplasmic $\mathbf{P P}_{\mathrm{i}}$ ase ( $\square$ ), $720 \mu \mathrm{mol} \mathrm{P}_{\mathrm{i}} \mathrm{h}^{-1}$ (mg protein) $)^{-1}$.

\section{Evidence that the pyrophosphatase of respiratory} membranes is a membrane-bound enzyme

M. Baltscheffsky et al. (1966) showed that 1-butanol is a specific inhibitor of membrane-bound pyrophosphatase of chromatophores of $R$. rubrum but inhibits neither the cytoplasmic pyrophosphatase nor $\mathrm{H}^{+}$-ATPase. Fig. 3 shows inhibition as a function of 1-butanol concentration. The pyrophosphatase of respiratory membranes was inhibited in the same fashion as that of chromatophores. This result further indicates that the pyrophosphatase activity of respiratory membranes was due to a membrane-bound enzyme and is not the result of cytoplasmic pyrophosphatase contamination.

To support the above suggestion, the respiratorymembrane pyrophosphatase was solubilized with different concentrations of Triton X-100 (Fig. 4). In (a), the specific activity in the supernatant is shown. When the concentration of Triton X-100 was increased, enzyme was liberated from the membrane. Moreover, the specific activity was enhanced when soybean phospholipids were added to the measurement reaction mixture. More than $80 \%$ of the initial activity of the membrane was released with Triton X-100 (Fig. $4 b$ ). Other treatments, such as exposure to high ionic strength or washings with chelators, did not release the enzyme (data not shown).

In summary, the respiratory-membrane pyrophosphatase is an integral membrane protein according to the criteria of Singer \& Nicolson (1972). This conclusion is 

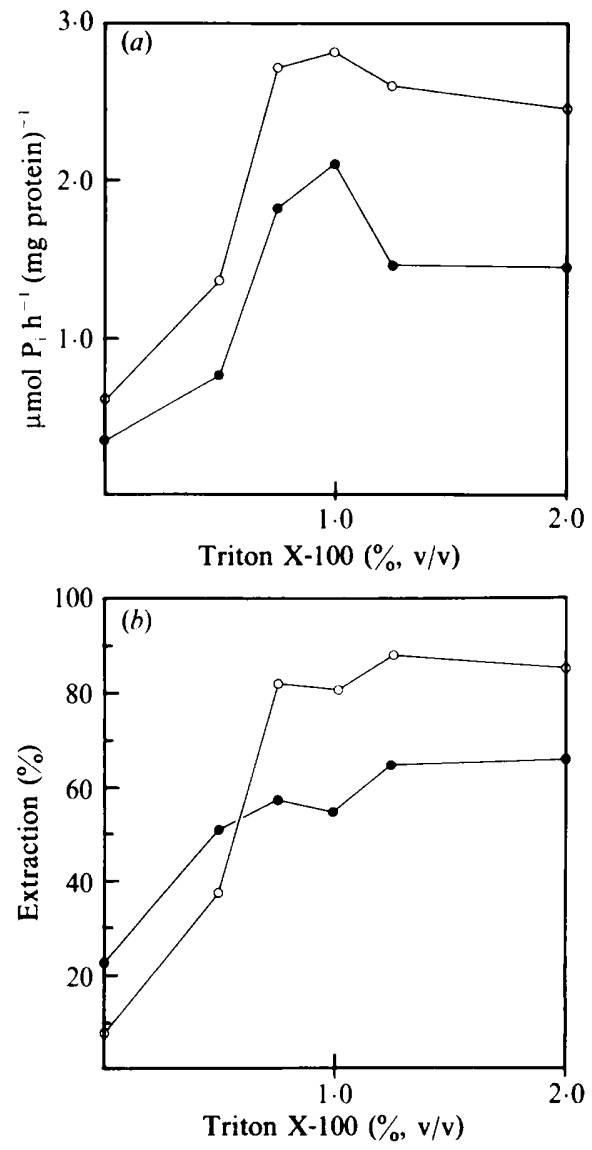

Fig. 4. Solubilization of the membrane-bound pyrophosphatase from respiratory membranes with Triton $\mathrm{X}-100$. The solubilization was done as indicated in Methods. (a) The supernatant fractions were analysed for pyrophosphatase activity as in Fig. 1 at $\mathrm{pH} 6.5$. The final concentration of supernatant protein in the assay tubes was $3 \mathrm{mg}$. The activity was measured with $(\mathrm{O})$ and without $(\bullet)$ phospholipids. (b) Percentage extraction, expressed on the basis of activity (with phospholipids, O) and protein (๑).

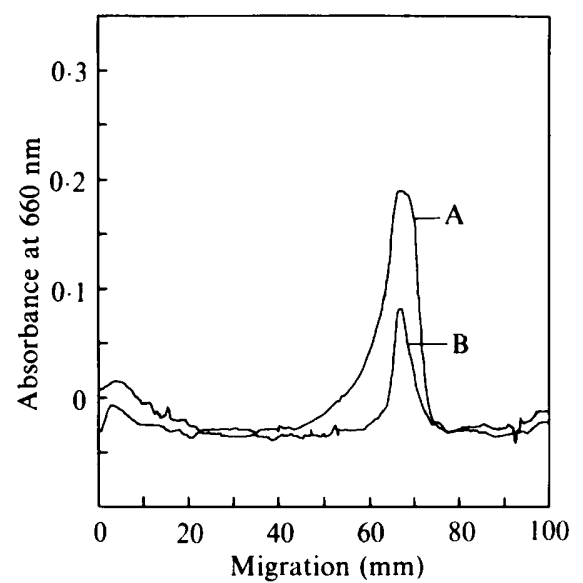

Fig. 5. Densitometric trace of non-denaturing polyacrylamide gel after electrophoresis of solubilized membrane-bound pyrophosphatases. Triton X-100 solubilized photosynthetic $(a)$ and respiratorymembrane-bound $(b)$ pyrophosphatases were run and the gels were stained for hydrolytic activity as stated in Methods.

supported by the following facts: the respiratorymembrane pyrophosphatase was inhibited by 1-butanol, which inhibits only the membrane-bound pyrophosphatase (M. Baltscheffsky et al., 1966) (Fig. 3), and the enzyme activity was released from the membrane by treatment with Triton $\mathrm{X}-100$ and requires phospholipids for maximal activity.

\section{Structural similarities between membrane-bound pyrophosphatases of respiratory and photosynthetic membranes}

To determine the structural similarities between the two membrane-bound pyrophosphatases, an electrophoretic analysis of the activities was performed (Fig. 5). A

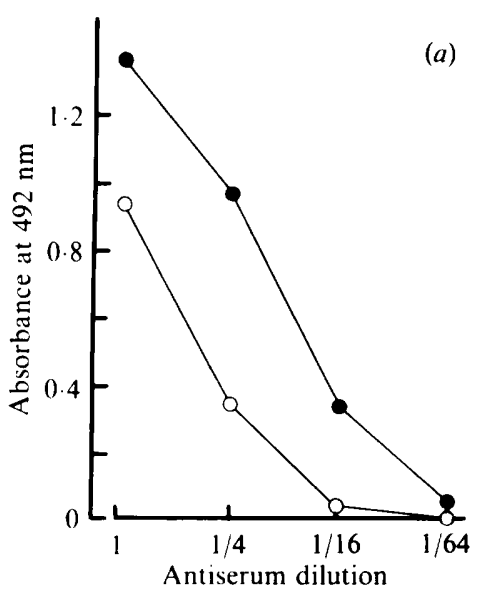

a)

(b)

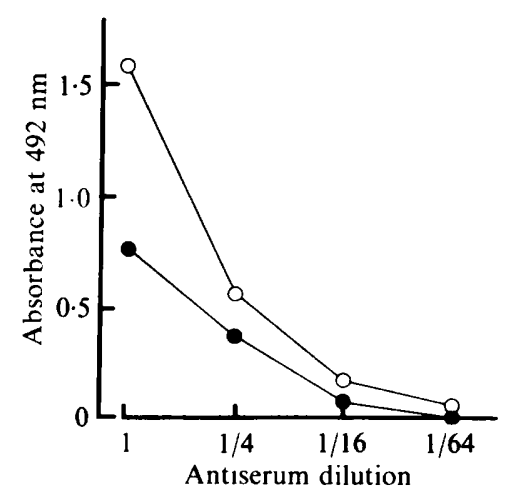

Fig. 6. Cross-reactivity of antibodies raised against photosynthetic and respiratory membrane-bound pyrophosphatases. In panel (a), solubilized photosynthetic membrane-bound pyrophosphatase $(640 \mu \mathrm{g}$ protein per well) was used as the basis for the indirect ELISA assay. In panel $(b)$, solubilized membrane-bound pyrophosphatase from respiratory membranes $(640 \mu \mathrm{g}$ protein per well) was used as the basis for the assay. Antisera vs photosynthetic membrane-bound pyrophosphatase (๑); antisera vs respiratory membrane-bound pyrophosphatase $(O)$. 
single band for both enzymes migrated to the same position, suggesting the same overall charge. Furthermore, the cross reactivity of mouse antibodies to the two proteins was tested by ELISA, using membrane-bound pyrophosphatase of photosynthetic membranes as base for antibody union assay (Fig. 6a) or membrane-bound pyrophosphatase from respiratory membranes (Fig. $6 b$ ). The binding was higher for the homologous antigen and antibody in each case, but the heterologous antibodies bound efficiently to the heterologous antigen, indicating structural similarities between the two enzymes.

The collected results suggest that membrane-bound pyrophosphatase is the same molecular entity in both photosynthetic and respiratory growing cells. The findings constitute the first evidence of the existence of a membrane-bound pyrophosphatase in respiratory membranes of the photosynthetic bacterium $R$. rubrum.

We thank Juan Quinto for his help with the initial experiments of this work. This work was partially supported by grant D111-903553 from CONACyT, Mexico.

\section{References}

BaltschefFSky, H., Von Stedingk, L. V., Heldt, H. W. \& KLINGENBERG, M. (1966). Inorganic pyrophosphate: formation in bacterial photophosphorylation. Science 153, 1120-1124.

BaltschefFSKY, M., BaltschefFSKy, H. \& Von StedingK, L. V. (1966). Light-induced energy conversion and the inorganic pyrophosphatase reaction in chromatophores from Rhodospirillum rubrum. Brookhaven Symposia in Biology 19, 246-257.

BALTSCHEFFSKY, M., BALTSCHEFFSKY, H. \& BOORK, J. (1982). Evolutionary and mechanistic aspects on coupling and phosphorylation in photosynthetic bacteria. In Electron Transport and Photophosphorylation. Topics in Photosynthesis, vol. 4, 249-272. Edited by J. Barber. New York: Elsevier Biomedical Press.

Celis, H., Romero, I. \& Gómez-PuYou, A. (1985). The phosphatepyrophosphate exchange and hydrolytic reactions of the membranebound pyrophosphatase of Rhodospirillum rubrum: effects of $\mathrm{Mg}^{2+}$, phosphate and pyrophosphate. Archives of Biochemistry and Biophysics 236, 766-774.

CELIS, H. \& Romero, I. (1987). The phosphate-pyrophosphate exchange and hydrolytic reactions of the membrane-bound pyrophosphatase of Rhodospirillum rubrum: effects of $\mathrm{pH}$ and divalent cations. Journal of Bioenergetics and Biomembranes 19, 255-272.

Clayton, R. K. (1963). Toward the isolation of a photochemical reaction center in Rhodopseudomonas sphaeroides. Biochimica et Biophysica Acta 75, 312-323.

Cohen-Bazire, G., Sistrom, W. B. \& Stanier, R. Y. (1957). The kinetic studies of pigment synthesis by non-sulfur purple bacteria. Journal of Cellular and Comparative Physiology 49, 25-68.

Davis, B. J. (1964). Disc electrophoresis. II. Methods and application to serum proteins. Annals of the New York Academy of Sciences 121, 404-427.
Fenoll, C. \& Ramírez, J. M. (1984). Simultaneous presence of two terminal oxidases in the respiratory system of dark aerobically grown Rhodospirillum rubrum. Archives of Microbiology 137, 42-46.

GUILlORY, R. J. \& FisheR, R. R. (1972). Studies on the light-dependent synthesis of inorganic pyrophosphate by Rhodospirillum rubrum chromatophores. Biochemical Journal 129, 471-481.

Kagawa, Y. \& RaCker, E. (1966). Partial resolution of the enzymes catalyzing oxidative phosphorylation. IX. Reconstitution of oligomycin-sensitive triphosphatase. Journal of Biological Chemistry 241, 2467-2474.

KeISTER, D. L. \& Minton, N. J. (1971a). ATP synthesis driven by inorganic pyrophosphate in Rhodospirillum rubrum chromatophores. Biochemical and Biophysical Research Communications 42, 932-939.

KEISTER, D. L. \& MiNTON, N. J. (1971b). Energy-linked reactions in photosynthetic bacteria. VI. Inorganic pyrophosphate-driven ATP synthesis in Rhodospirillum rubrum. Archives of Biochemical and Biophysics 147, 330-338.

Klemme, J. H. \& Gest, H. (1971). Regulation of the cytoplasmic inorganic pyrophosphatase of Rhodospirillum rubrum. European Journal of Biochemistry 22, 529-537.

LATHI, R. (1983). Microbial inorganic pyrophosphatases. Microbiological Reviews 47, 169-179.

Melandri, B. A., Baccarini-Melandri, A., San Pietro, A. \& Gest, H. (1971). Interchangeability of phosphorylation coupling factors in photosynthetic and respiratory energy conversion. Science 174, 514-516.

Moyle, J., Mitchell, R. \& Mitchell, P. (1972). Proton-translocating pyrophosphatase of Rhodospirillum rubrum. FEBS Letters 23, 233-236.

Nakamura, R. M., Voller, A. \& Bidwell, D. E. (1986). Enzyme immunoassays: heterogeneous and homogeneous systems. In Handbook of Experimental Immunology, vol. 1, pp. 27.1-27.20. Edited by D. M. Weir. Great Britain: Blackwell Scientific Publications.

NYRÉN, P. \& BALTSCHEFFSKY, M. (1983). Inorganic pyrophosphatedriven ATP-synthesis in liposomes containing membrane-bound inorganic pyrophosphatase and $\mathrm{F}_{0}-\mathrm{F}_{1}$ complex from Rhodospirillum rubrum. FEBS Letters 155, 125-130.

Nyrén, P., Hajnal, K. \& Baltscheffsky, M. (1984). Purification of the membrane-bound proton-translocating inorganic pyrophosphatase from $R$. rubrum. Biochimica et Biophysica Acta 766, 630-635.

Pilosoph, S., Binder, A. \& Gromet-Elhanan, Z. (1977). Coupling factor ATPase complex of Rhodospirillum rubrum. Journal of Biological Chemistry 252, 8747-8752.

RANDAHL, H. (1979). Characterization of the membrane-bound inorganic pyrophosphatase in Rhodospirillum rubrum. European Journal of Biochemistry 102, 251-256.

SChmid, R., Kiltz, H. H., SChNeider, E. \& Altendorf, K. (1981) Characterization of the dicyclohexylcarbodiimide-reactive protein from Rhodospirillum rubrum grown in the light and in the dark. FEBS Letters 125, 97-100.

SEBALD, W. \& HoPPE, J. (1981). On the structure and genetics of the proteolipid subunit of the ATP synthase complex. Current Topics in Bioenergetics 12, 1-64.

Singer, S. J. \& Nicolson, G. L. (1972). The fluid mosaic model of the structure of cell membranes. Science 175, 720-731

SUMNER, J. B. (1944). A method for the colorimetric determination of phosphorus. Science 100, 413-415.

Taniguchi, S. \& Kamen, M. D. (1965). The oxidase system of heterotrophically grown Rhodospirillum rubrum. Biochimica et Biophysica Acta 95, 395-428.

Thorne, A., Keister, D. L. \& San Pietro, A. (1969). Studies on the respiratory system of aerobically (dark) and anaerobically (light) grown Rhodospirillum rubrum. Archives of Microbiology 67, 378-396. 